\title{
Morphology of eggs of Dioctophyme renale Goeze, 1782 (Nematoda: Dioctophymatidae) and influences of temperature on development of first-stage larvae in the eggs
}

\author{
Morfologia de ovos de Dioctophyme renale Goeze, 1782 (Nematoda: Dioctophymatidae) e influência \\ da temperatura no desenvolvimento de larvas de primeiro estágio nos ovos \\ Daniela Pedrassani ${ }^{1 *}$; Estevam Guilherme Lux Hoppe ${ }^{2}$; Neuri Avancini ${ }^{3}$; Adjair Antonio do Nascimento ${ }^{4}$

\begin{abstract}
${ }^{1}$ Medicina Veterinária, Universidade do Contestado - UnC e Aluna do Programa de Pós-graduação em Medicina Veterinária da Faculdade de Ciências Agrárias e Veterinárias - FCAV, Universidade Estadual Paulista - UNESP

${ }^{2}$ Medicina Veterinária, Centro Universitário de Rio Preto - UniRP e Aluno do Programa de Pós-graduação em Medicina Veterinária da Faculdade de Ciências Agrárias e Veterinárias - FCAV, Universidade Estadual Paulista - UNESP

${ }^{3}$ Laboratorista Técnico, Universidade do Contestado - UnC

${ }^{4}$ Departamento de Medicina Veterinária Preventiva e Reproduçāo Animal da Faculdade de Ciências Agrárias e Veterinárias - FCAV, Universidade Estadual Paulista - UNESP
\end{abstract}

Received January 27, 2009

Accepted February 27, 2009

\begin{abstract}
This study aims to provide information on morphological data of $D$. renale eggs, as well as on first-stage larvae development into eggs kept at different temperatures. Eggs were obtained by centrifugation of infected dog urine, placed in Petri dishes, and stored in BOD chamber for a 90-day period. Each treatment (GI $-15^{\circ} \mathrm{C}$, GII $-20^{\circ} \mathrm{C}$, and GIII $-26^{\circ} \mathrm{C}$ ) was repeated five times. Eggs showed average measures of $67.23 \times 42.78 \mu \mathrm{m}$, and the mean incubation time was inversely proportional to the incubation temperature. Larvae motility was observed one week after being observed in eggs.
\end{abstract}

Keywords: Dioctophyme renale, dog, eggs, temperature.

\section{Resumo}

Este estudo teve a finalidade de fornecer dados morfológicos de ovos de $D$. renale e do desenvolvimento de larvas de primeiro estádio em ovos mantidos em diferentes temperaturas. Os ovos foram obtidos por centrífugação da urina de cáes parasitados e colocados em placas de Petri em estufa BOD, durante 90 dias. $\mathrm{O}$ experimento consistiu de três tratamentos $\left(\mathrm{GI}-15^{\circ} \mathrm{C}, \mathrm{GII}-20^{\circ} \mathrm{C}\right.$ e GIII $\left.-26^{\circ} \mathrm{C}\right)$ com cinco repetiçóes cada. Os ovos apresentaram tamanho médio de $67,23 \times 42,78 \mu \mathrm{m}$, e o tempo médio de incubação foi inversamente proporcional à temperatura de incubação e as larvas apresentaram motilidade por aproximadamente uma semana após sua formação.

Palavras-chave: Dioctophyme renale, cão, ovos, temperatura.

\section{Introduction}

Dioctophyme renale Goeze, 1782 (Enoplida: Dioctophymatidae) commonly known as the giant kidney worm, is the largest known nematode, and can have sizes up to $100 \mathrm{~cm}$ in length by $1.2 \mathrm{~cm}$ in width (ANDERSON, 2000; MONTEIRO et al., 2002; FORTES, 2004).

It can be found worldwide parasitizing domesticated and wild carnivores and mustelids (ANDERSON, 2000; COSTA et al., 2004). Mustela vison (Carnivore: Mustelidae) is considered its main definitive host (BOWMAN, 2006). According to Kommers et al. (1999) and Nakagawa et al. (2007), the dog is

\footnotetext{
${ }^{*}$ Corresponding author: Daniela Pedrassani

Curso de Medicina Veterinária, Universidade do Contestado - UnC

Rua Roberto Ehlke, 85, CEP 89460-000 Canoinhas - SC, Brazil

e-mail:daniela@cni.unc.br
}

considered an unusual and terminal or accidental definitive host of the parasite (ACHA and SZYFRES, 1986).

In the parasite life-cycle, the eggs are eliminated through the urine of the definitive host to reach their infective stage in the external environment (ANDERSON, 2000). Eggs are brown, barrel-shaped, with a thick, rough shell and bipolar plugs (SLOSS et al., 1999).

These eggs lose their viability if desiccated by the sun (LUKASIAK, 1930 apud COYNER et al., 2004). The first step of the development inside the eggs occurs only if they have contact with fresh water containing the oligochaete annelid Lumbriculus variegatus. Eggs must be ingested by this intermediate host in order to develop into infective larvae of third 
stage (ANDERSON, 2000). The main method for diagnosis relies on the detection of eggs in the urine (COSTA et al., 2004; MONTEIRO et al., 2002). Diagnosis may also be done when parasites are occasionally found either during abdominal surgery or at necropsy (PEREIRA et al., 2006). For this reason, knowing the morphology of the egg is very important.

In order to better understand the biology and morphology of pre-parasite forms of $D$. renale in Brazil, a trial was run to provide data on egg morphology and to study the influence of temperature in the development of first-stage larvae into the parasite egg.

\section{Material and Methods}

\section{Collection of D. renale eggs}

To obtain the eggs, five samples each of $10 \mathrm{~mL}$ of urine were collected from each of nine parasitized dogs originally from Três Barras, state of Santa Catarina, Brazil. Samples were collected either via a bladder catheter or cystocentesis guided by ultrasound. Next, they were centrifuged at $1.500 \mathrm{rpm}$ for 10 minutes in order to concentrate the eggs in the samples. Finally, the obtained sediment containing the eggs was washed (with saline solution $-0.9 \%$ ) three times, each time followed by a new centrifugation at $1.500 \mathrm{rpm}$ for 10 minutes. After each centrifugation the top liquid portion was poured off.

\section{Morphometric evaluation}

A total of 102 parasite eggs found in the samples from nine parasitized dogs, were measured to determine their length and width. The largest parasite (length and width considered) was taken from each egg. The obtained measures (in $\mu \mathrm{m}$ ) were analyzed by ImagePro Plus v.4.1 software, which is suitable for measuring parasites. The images of the eggs were caught by the trinocular microscopy Olympus BX-51 equipped with digital camera QColor 3, with 3.1 mega pixels resolution.

\section{Temperature evaluation}

To verify the percentage of embryogenesis, the eggs were placed into a Petri dish with $3 \mathrm{~mL}$ of mineral water and kept for 90 days in the BOD incubator with photoperiod and humidity of approximately $80 \%$. The dishes were divided into three groups with five replications each: GI - at temperature of $15^{\circ} \mathrm{C}\left( \pm 0.5^{\circ} \mathrm{C}\right)$, GII - at temperature of $20^{\circ} \mathrm{C}\left( \pm 0.5^{\circ} \mathrm{C}\right)$, and GIII - at temperature of $26^{\circ} \mathrm{C}\left( \pm 0.5^{\circ} \mathrm{C}\right)$. Mineral water $\mathrm{pH}$ varied from 7.2 to 7.7. Every 2-3 days the dishes were analyzed with optical microscopy at $\times 400$ magnification, to observe the percentage of larvae eggs, mold and bacterial contamination, and egg viability.

\section{Egg solution suspension evaluation}

The suspensions of eggs were placed in Petri dishes and kept for 30 days in a BOD incubator at $26^{\circ} \mathrm{C}$. The dishes were divided into 2 treatments: T1 - egg sediment in mineral water $(\mathrm{pH}=7.2)$ and $\mathrm{T} 2$ - egg sediment in purified milliQ water with $0.1 \%$ formalin solution $(\mathrm{pH}=7.0)$. Each treatment was replica- ted 6 times. Every 2-3 days the dishes were analyzed in optical microscopy at $\times 400$ magnification to observe the percentage of larvae eggs, mold and bacterial contamination and egg viability.

\section{Statistical analysis}

The dimensions of the eggs that either her developed or not develop into larvae or did not, plus larvae and also the embryogenesis timing of $50 \%$ of the eggs, were statistically evaluated via using the Student Test $(\alpha=0,05)$ by MSTAC - C software v. 2.10 .

The egg solution suspension for embryogenesis was evaluated via Student Test $(\alpha=0,05)$ by MSTAC $-\mathrm{C}$ software v. $2 \cdot 10$ and the data was converted into Log (value +1$)$.

\section{Results and Discussion}

A total of 102 parasite eggs of $D$. renale from nine parasitized dogs were analyzed. Eggs showed an elliptical shape, generally with symmetrical and clear bipolar plugs, covered by a thick, rough shell. The color varied from transparent to yellow (Figure 1). The criteria to classify the eggs as from $D$. renale were the thickness and roughness of the shell, the stage of anembryonic egg, and the fact that they were collected from samples of dogs urine. According to Woodhead (1950) these are typical for Dioctophymatidae eggs. The same author described them as oval shaped and light brown to a yellowish color when obtained from kidneys. The size may vary from $60-80$ by $39-46 \mu \mathrm{m}$ (FREITAS, 1980; COSTA et al., 2004).

The thickness and roughness of the eggshell can play an important role in the parasite life cycle. Since eggs begin their development in water, the wavy surface of the shell can be an adaptation to increase its surface area, which may have improved the oxygen change in areas with low availability of dissolved oxygen. The pits and projections on the egg surface can work as point of attachment to plants, making the eggs more attractive to intermediate hosts.

Under natural conditions, eggs of Eustrongylides ignotus (Enoplida: Dioctophymatoidea) often adhere to particles and plants. Also, bacteria can be seen in the projections and pits of the shell. Many oligochaetes consume litter with bacteria, so the
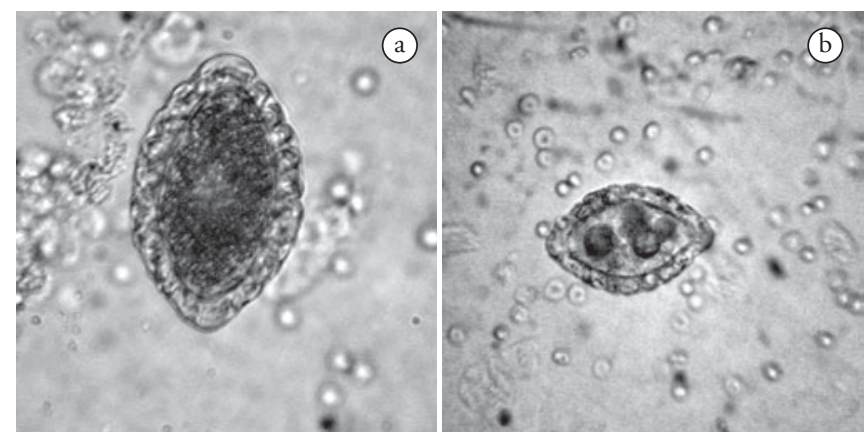

Figure 1. Eggs of Dioctophyme renale from the urine of parasitized dogs originally from Três Barras, SC, 2008. a) Fertile egg (640x) e b) Infertile egg (160x). 
bacterial presence on the eggs' shell can increase the chances that they will be eaten by these organisms (COYNER et al., 2003).

The length of the parasite eggs varied from 62.01 to $75.15 \mu \mathrm{m}(67.23 \pm 2.77)$ and the width from 36.36 to $53.03 \mu \mathrm{m}$ $(42.78 \pm 2.85)$.

Both fertile and infertile eggs were detected in the urine of the sampled dogs. Eggs that developed into larvae after incubation in the BOD incubator in liquid medium were classified as fertile. Those that, under the same conditions, did not develop any larvae were classified as infertile eggs. Fertile eggs presented lengths varying from 64.12 to $70.23 \mu \mathrm{m}(67.64 \pm 2.19)$ and width from 41.28 to $44.49 \mu \mathrm{m}(42.93 \pm 1.17)$ while for the same dimensions, infertile eggs varied from 62.59 to $75.15 \mu \mathrm{m}(67.62 \pm 2.98)$ and 36.36 to $51.53 \mu \mathrm{m}(42.73 \pm 3.43)$. Although a relative variation on both dimensions of the eggs could be noticed in the present study, no significant differences in length $(\mathrm{p}=0.9882, \mathrm{t}=0.0149$, $\mathrm{GL}=41)$ and width $(\mathrm{p}=0.7742, \mathrm{t}=0.2888, \mathrm{GL}=40)$ between fertile and infertile eggs incubated in the BOD at $26^{\circ} \mathrm{C}$ (Table 1) were found when compared to eggs of $D$. renale originally from kidney nodules of parasitized dogs. The difference in egg size may result from either the sexual maturity of the female parasite or from the fact that the parasite was laying unfertilized eggs. When comparing the absolute values, these measures seem similar to eggs of this nematode originally from parasitized $M$. vison.

Based upon the available literature, the authors (SCHACHER and FAUST, 1956; MACE and ANDERSON, 1975) concluded that eggs obtained from the uterus of female parasites were infertile when the definitive host was parasitized only with female and not male parasites. Only unfertilized eggs were obtained from kidney nodules hosting exclusively female parasites from Mustela vison slaughtered in Canada. These females presented dimensions of 73 by $42 \mu \mathrm{m}$ while those from females living in the nodules together with males were 73 by $52 \mu \mathrm{m}$. In this case, the difference in width between fertile and infertile eggs is statistically significant (MACE and ANDERSON; 1975). Woodhead (1950) described eggs from parasitized M. vison with dimensions of 74.3 by $46.7 \mu \mathrm{m}$.

Schacher and Faust (1956) evaluated 35 eggs from parasitized $M$. vison and the same number of eggs from a preserved material originally from a parasitized $\mathrm{dog}$. The results were infertile eggs measuring 68.7 by $42.4 \mu \mathrm{m}$ and 67.2 by $41.3 \mu \mathrm{m}$ respectively, and they considered the dimensions of eggs originally from the two species to be similar.
Egg development is fundamental for continuing the biological cycle of $D$. renale and depends on the temperature (FREITAS, 1980). The optimal temperature required for egg embryogenesis is between 25 and $30{ }^{\circ} \mathrm{C}$, under which conditions in 30 days the first-stage larvae are observed; however in low temperatures timing can take up to 7 months (FREITAS, 1980).

Most of the obtained eggs presented a single cell in their interior and some of them two. From the nine dogs in this study, eight had eggs containing only one cell at the moment of being collected in the urine, while only the last one had eggs containing two cells. Both sorts of eggs developed their embryo to larvae after incubation. At the eighth day of incubation at $26{ }^{\circ} \mathrm{C}$, four to eight cells were visible (Figure 2). Mace and Anderson (1975) noticed that many embryonic eggs removed from the uterus of female parasites presented no larvae inside but two embryonic cells, while few presented a single cell in their interior; however only those containing two cells developed their embryo to larvae stage. Woodhead (1950) observed that most of the eggs removed from the uterus of female parasites hosted by $M$. vison presented two cells inside and remained in this status up to the moment they were exposed to oxygen.

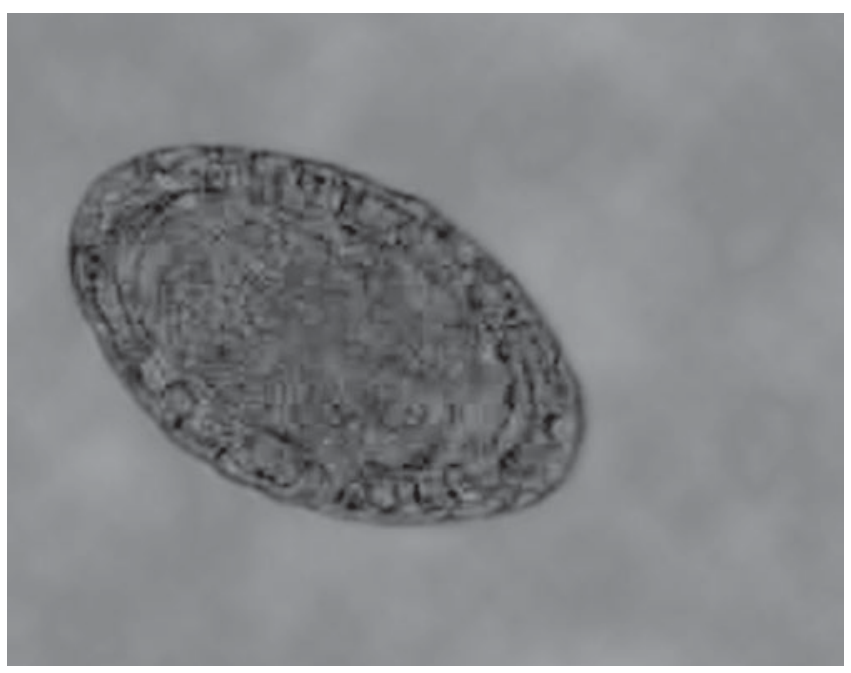

Figure 2. Egg of Dioctophyme renale by the eighth day of incubation with eight cells inside (200x).

Table 1. Comparison of egg dimensions of Dioctophyme renale from different published works.

\begin{tabular}{lcccc}
\hline \multicolumn{1}{c}{ Egg status } & Length $(\mu \mathbf{m})$ & Width $(\mu \mathbf{m})$ & Host & Source \\
\hline Unaccounted & 74.3 & 46.7 & Mustela vison & Woodhead (1950) \\
Infertile & 68.7 & 42.4 & M. vison & Schacher and Faust $(1956)$ \\
Infertile & 67.2 & 41.3 & Dog & Schacher and Faust $(1956)$ \\
Infertile & 73 & 42 & M. vison & Mace and Anderson (1975) \\
Fertile & 73 & 52 & M. vison & Present work \\
Infertile & 67.62 & 42.73 & Dog & Dog \\
Fertile & 67.64 & 42.93 & &
\end{tabular}


Embryogenesis was completed at the three evaluated temperatures. However, the temperature of incubation affected the timing to reach the first-stage larvae status for $50 \%$ of the eggs of D. renale. Under 15,20 and $26^{\circ} \mathrm{C}$ incubation medium, timing was 78,48 , and 18 days respectively. Statistically, these times were significantly different for the three evaluated temperatures $(15 \times 20 \mathrm{t}=3.3208, \mathrm{p}=0.016, \mathrm{GL}=6 ; 15 \times 26 \mathrm{t}=13.7302$, $\mathrm{p}=0.00, \mathrm{GL}=5 ; 20 \times 26 \mathrm{t}=3.8654, \mathrm{p}=0.0062, \mathrm{GL}=7)$. One replication from GI and two from GIII presented mold contamination and were discharged.

Egg development was influenced by the temperature: the higher the temperature, the shorter the development time (Figure 3). The same evolutional behavior was observed for E. ignotus, which reached first-stage larvae after 17 and 28 days under incubation temperatures of 28 and $19.5^{\circ} \mathrm{C}$ respectively (COYNER et al., 2004).

First-stage larvae of $D$. renale reach their development in water when incubated at a temperature of $14-30{ }^{\circ} \mathrm{C}$, although the development rate varies according to the temperature (MACE and ANDERSON, 1975). At $20{ }^{\circ} \mathrm{C}$, they were completely developed in approximately 35 days (MACE and ANDERSON, 1975). In the present work, at the same temperature, they reached their stage in 48 days. Woodhead (1950) observed larvae development after 21 days of incubation at room temperature.

The first-stage larvae formed inside the eggs presented evident motility for about a week after their formation (Figure 4). This was similar to what was observed by Woodhead (1950) and Mace and Anderson (1975).

The fact that their development depends on the temperature can indicate an adaptation to the population flow of intermediate (MEASURES, 1988 apud COYNER et al., 2003) and parate-

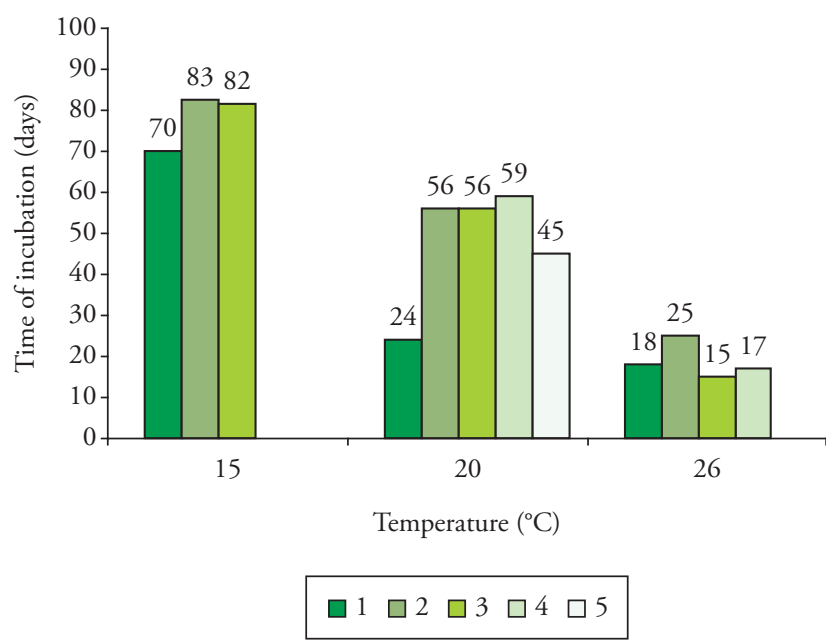

Figure 3. Timing versus temperature of incubation for embryogenesis of $50 \%$ of Dioctophyme renale eggs.
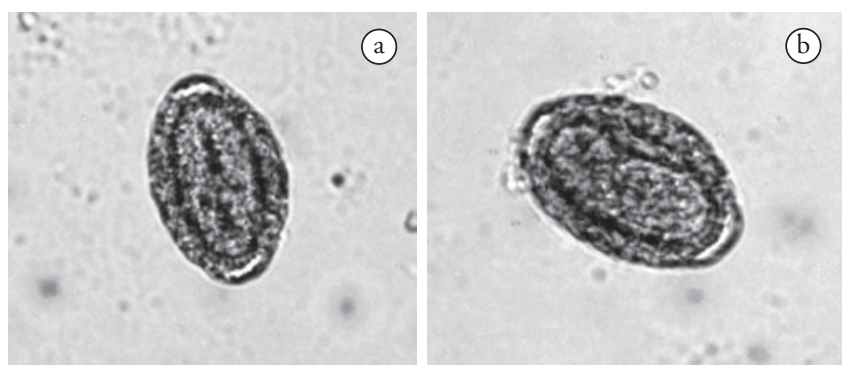

Figure 4. Larvae eggs of Dioctophyme renale by the eighteenth day of incubation (200x).
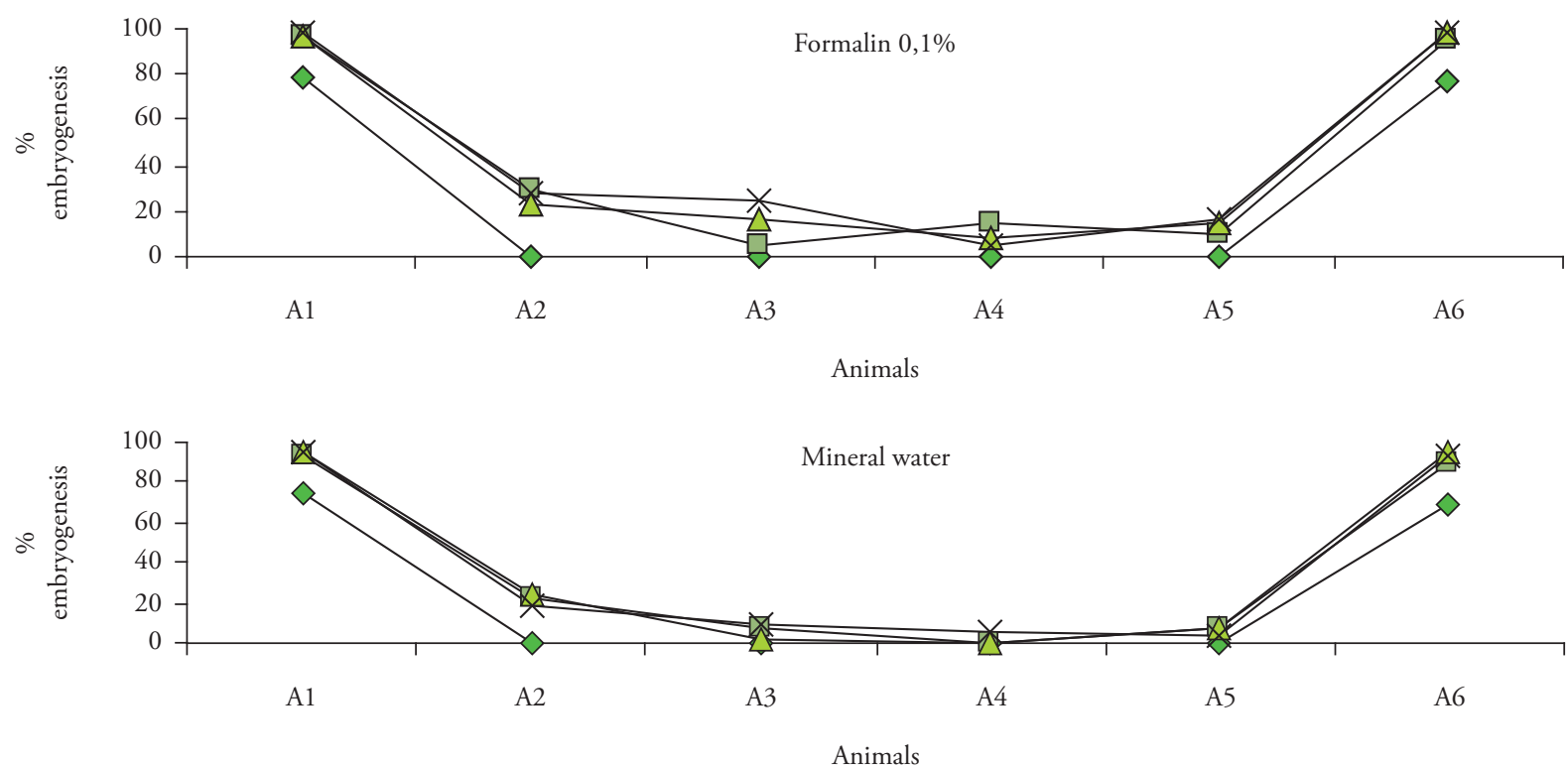

$\checkmark$ April 19,2007 $\rightarrow$ April 21, $2007 \quad \square$ April 20,2007 $\rightarrow$ April 22, 2007

Figure 5. Percentage of embryogenesis of Dioctophyme renale eggs incubated at $26^{\circ} \mathrm{C}$ temperature versus incubation medium. 
nic hosts. Despite the fact that eggs reach their development faster under conditions of high temperature, this parasitism occurs more often in places of cold weather, where the low temperature during some period of the year contributes to extending the development of the helminthes. Other factors such as $\mathrm{pH}$, water salinity, or availability of hosts can be responsible for a higher parasite presence in regions of colder weather.

Eggs incubated in mineral water and in purified milliQ water with $0.1 \%$ formalin solution presented normal development. Statistically, there were no significant differences between the treatments $(\mathrm{p}=0.5529, \mathrm{t}=-0.5959$, $\mathrm{GL}=82)$. Thus, $D$. renale eggs can be cultured in either of the two tested mediums (Figure 5). However, the use of formalin solution reduced and/or avoided the mold and bacterial growth, especially in the cases in which the parasitized dog carried bacterial infection in the urinary tract.

\section{Conclusions}

Eggs of $D$. renale originally from parasitized dogs presented medium length of $67.23 \mu \mathrm{m}$ and width of $42.78 \mu \mathrm{m}$. Statistically; the length and width of fertile and infertile eggs presented no significant difference. Parasite eggs can be incubated for embryogenesis either in mineral water or in purified milliQ water with $0.1 \%$ formalin solution. However, the temperature of incubation interferes with their timing development. The medium incubation timing for the parasite eggs was inversely proportional to the incubation temperature.

Other factors such as $\mathrm{pH}$ and water salinity should be evaluated in order to verify their effect on the egg embryogenesis.

\section{References}

ACHA, P. N.; SZYFRES, B. Dioctofimosis. In: ACHA, P. N.; SZYFRES, B. Zoonosis y Enfermedades Transmisibles Comunes al Hombre y a los Animales. 2 ed. Washington: OPS, 1986. p. 806-809.

ANDERSON, R. C. Nematode parasites of vertebrates: Their development and transmission. 2 ed. Canada: University of Guelph, 2000. p. 595-597.
BOWMAN, D. D. Parasitologia Veterinária de Georgis. 8 ed. São Paulo: Manole, 2006. p. 224.

COSTA, P. R. S. et al. Dioctofimose e leptospirose em um cão - relato de caso. Revista Clínica Veterinária. Ano 9, n. 51, p. 48-50, 2004.

COYNER, D. F.; SPALDING, M. G.; FORRESTER, D. J. Epizootiology of Eustrongylides ignotus in Florida: Transmission and development of larva in intermediate hosts. Journal of Parasitology, v. 89 , n. 2 , p. $290-298,2003$.

COYNER, D. F.; SPALDING, M. G.; FORRESTER, D. J. Influences of salinity and desiccation on development of first-stage larvae in the egg of Eustrongylides ignotus and their impact on the Epizootioligy of Eustrongylides ignotus in Florida, U.S.A. Comparative Parasitology, v. 71, n. 2, p. 262-263, 2004.

FORTES, E. Parasitologia veterinária. São Paulo: ÍCONE, 2004. p. $370-372$.

FREITAS, M. G. Helmintologia Veterinária. 4 ed. Belo Horizonte: Rabelo, 1980. p. 267-270.

KOMMERS, G. D.; ILHA, M. R. S.; BARROS, C. S. L. Dioctofimose em case: 16 casos. Ciência Rural, v. 29, n. 3, p. 517-522, 1999.

MACE, T. F.; ANDERSON, R. C. Development of the giant kidney worm, Dioctophyma renale (Goeze, 1782) (Nematoda: Dioctophymatoidea). Canadian Journal of Zoology, v. 53, n. 11, p. $1552-1538,1975$.

MONTEIRO, S. G.; SALLIS, E. S. V.; STAINKI, D. R. Infecção natural por trinta e quatro helmintos da espécie Dioctophyma renale (Goeze,1782) em um cão. Revista da Faculdade de Zootecnia, Veterinária e Agronomia de Uruguaiana, v. 9, n. 1, p. 29-32, 2002.

NAKAGAWA, T. L. D. R. et al. Giant kidney worm (Dioctophyma renale) infections in dogs from Northern Paraná, Brazil. Veterinary Parasitology, v. 145, n. 3-4, p 366-370, 2007.

SCHACHER, J. F.; FAUST, E. C. Occurrence of Dioctophyma renale in Louisiana, with remarks on the size of infertile eggs of this species. Journal of Parasitology, v. 42, n. 5, p. 533-535, 1956.

SLOSS, M. W.; ZAJAC, A. M.; KEMP, R. L. Parasitologia clínica veterinária. São Paulo: Manole Ltda, 1999. p. 94-97.

WOODHEAD, A. E. Life history cycle of the giant kidney worm, Dioctophyma renale (Nematoda), of man and many other mammals. Transactions of the American Microscopical Society, v. 69, n. 1, p. 21-46, 1950. 